\title{
The vagus nerve and autonomic imbalance in heart failure: past, present, and future
}

\author{
Paul J. Hauptman · Douglas L. Mann
}

Published online: 30 December 2010

(C) Springer Science+Business Media, LLC 2010

Advances in heart failure (HF) therapeutics over the last 20 years have led to widespread acceptance and use of oral antagonists of the renin-angiotensin-aldosterone (RAAS) and sympathetic nervous (SNS) systems $[1,2]$ in patients with a depressed ejection fraction. In addition, implantable cardioverter defibrillators and cardiac resynchronization devices (CRT) have been widely adopted in both practice guidelines and clinical care [3-5]. Nevertheless, with the aging of the population and rising disease prevalence, interest in the development of newer approaches has continued, and several are now under investigation $[6,7]$. The need for novel paradigms is further highlighted by the fact that intensification of antagonism of the RAAS has not been shown to reduce mortality [8-10], and other pharmacologic and device approaches including anticytokine therapy, epicardial constraining devices, and novel stimulation technologies have not been convincingly associated with improvements in hard clinical outcomes [11-13]. There are also multiple clinical scenarios that suggest areas of unmet need in HF such as CRT non-responders and patients who are not candidates for CRT due to narrow complex QRS morphologies [14, 15]. Thus, there continues to be a need for innovative therapies for patients with heart failure.

\section{P. J. Hauptman}

Department of Medicine, Saint Louis University School of Medicine, St. Louis, MO, USA

D. L. Mann

Department of Medicine, Washington University School of Medicine, St. Louis, MO, USA

\section{P. J. Hauptman $(\bowtie)$}

Division of Cardiology, FDT-15, Saint Louis University Hospital, 3635 Vista Avenue, St. Louis, MO 63110, USA e-mail: hauptmpj@slu.edu
One area of recent focus in heart failure research has been the role of autonomic imbalance. In particular, there is increasing evidence that in addition to increased sympathetic activation, parasympathetic withdrawal may also contribute to the pathogenesis of heart failure [16]. However, while beta-blockade has found its place as a leading disease modifying therapy that impacts the sympathetic nervous system, far less is known about methods to augment parasympathetic function.

In this context, the topics of vagus nerve anatomy, physiology and influence on cardiac function are reviewed in detail in the current issue of Heart Failure Reviews. These papers form a foundation for understanding the clinical potential of a new intervention, vagus nerve stimulation (VNS). Pre-clinical data (including models of acute ischemia and chronic failure) and phase II experience in Europe with VNS are reviewed as are other potential ways to influence vagus nerve function.

The current issue begins with a historical overview of experimental physiologic and clinical-translational work performed by Dr. Peter Schwartz and colleagues, on parasympathetic-sympathetic interactions in both ischemic heart disease and heart failure [17]. Drs. Chapleau and Sabharwal provide a highly detailed review of the concepts of cardiovagal tone, parasympathetic modulation, parasympathetic re-activation, and reflex changes in heart rate and the methods used to assess them [18]. Normal vagus nerve anatomy is described in an elegant paper by Bibevski and Dunlap, who discuss the multitude of potential sites that might contribute to impaired parasympathetic nerve activity and offer evidence that points to specific locations of the defects, including the post-ganglionic nicotinic acetylcholine receptor [19]. The potential mechanisms that mediate the effects of VNS in heart failure are discussed by Li and Olshansky, who review the influence of efferent and 
afferent limbs of the parasympathetic system on inflammation, as well as the role of nitric oxide [20]. Vagus nerve stimulation is also a focus of several other papers, including a comprehensive review by Zhang and Mazgalev on the impact of stimulation on atrial fibrillation, atrioventricular conduction, and ventricular arrhythmia generation [21]. An overview of the safety of VNS is provided by Cohen and Georgievskaya who first describe the impact of various forms of nerve injury (compressive, inflammatory, and electrical) and then present a histopathological evaluation of the effects of stimulation on the vagus nerve itself, using tissue derived from pre-clinical studies [22]. These safety assessments are important in light of the data generated by Sabbah [23] demonstrating that VNS has a beneficial effect on left ventricular remodeling in the canine infarct model [23]. Indeed, these experimental data provided ample support for the initiation of human studies, including a recently completed open label study in patients with left ventricular dysfunction and advanced heart failure symptoms despite optimal medical therapy [7, 24]. VNS is of course only one methodology by which parasympathetic tone can theoretically be increased. In a review of pharmacologic studies, Desai and colleagues describe often conflicting data that have been published on the impact of conventional heart failure medications on indices of parasympathetic system function. They also outline the limitations of human studies including the use of surrogate end points such as heart rate variability [25].

The long arc from anatomic and physiologic studies to pre-clinical experiments to clinical trials in humans is summarized by de Ferrari and Schwartz in a thoughtful concluding paper [26]. Taken together, the articles presented in this issue of heart failure reviews suggest that augmentation of parasympathetic tone is an attractive therapeutic target in patients with heart failure and a depressed ejection fraction. Nevertheless, as highlighted by a number of the contributors, important gaps in knowledge remain. Therefore, despite preliminary efficacy signals, the final evaluation of VNS requires the ultimate test: a large clinical trial.

\section{References}

1. Anonymous (1991) Effect of enalapril on survival in patients with reduced left ventricular ejection fractions and congestive heart failure. The SOLVD Investigators. N Engl J Med 325:293-302

2. Packer M, Bristow MR, Cohn JN, Colucci WS, Fowler MB, Gilbert EM, Shusterman NH (1996) The effect of carvedilol on morbidity and mortality in patients with chronic heart failure. US carvedilol heart failure study group. N Engl J Med 334: 1349_ 1355

3. Jessup M, Abraham WT, Casey DE, Feldman AM, Francis GS, Ganiats TG, Konstam MA, Mancini DM, Rahko PS, Silver MA, Stevenson LW, Yancy CW (2009) Writing on behalf of the 2005 guideline update for the diagnosis and management of chronic heart failure in the adult writing committee. 2009 Focused update: ACCF/AHA guidelines for the diagnosis and management of heart failure in adults: a report of the American College of Cardiology Foundation/American Heart Association task force on practice guidelines. Circulation 119:1977-2016

4. Cleland JG, Daubert JC, Erdmann E, Freemantle N, Gras D, Kappenberger L, Tavazzi L (2005) The effect of cardiac resynchronization on morbidity and mortality in heart failure. N Engl J Med 352:1539-1549

5. ICD registry 2010 http://www.ncdr.com/webncdr/ICD/default. aspx. Accessed 1 Dec 2010

6. Teerlink JR, Metra M, Felker GM, Ponikowski P, Voors AA, Weatherley BD, Marmor A, Katz A, Grzybowski J, Unemori E, Teichman SL, Cotter G (2009) Relaxin for the treatment of patients with acute heart failure (Pre-RELAX-AHF): a multicentre, randomised, placebo-controlled, parallel-group, dose-finding phase IIb study. Lancet 373:1429-1439

7. de Ferrari GM, Crijns HJGM, Borggrefe M, Milasinovic G, Smid J, Zabel M, Gavazzi A, Sanzo A, Kuschyk J, Raspopovic S, Klein H, Swedberg K, Schwartz PJ (2010) Chronic vagus nerve stimulation: a new and promising therapeutic approach for chronic heart failure. Eur Heart J. doi:10.1093/eurheartj/ehq391

8. Cohn JN, Tognoni G (2001) The effect of the angiotensin receptor blocker valsartan on morbidity and mortality in heart failure. N Engl J Med 345:1667-1675

9. McMurray JJ, Ostergren J, Swedberg K, Granger CB, Held P, Michelson EL, Olofsson B, Yusuf S, Pfeffer MA (2003) Effects of candesartan in patients with chronic heart failure and reduced leftventricular systolic function taking angiotensin-convertingenzyme inhibitors: the CHARM-Added trial. Lancet 362:767-771

10. Krum H, Maggioni A (2010) Renin inhibitors in chronic heart failure: the aliskiren observation of heart failure treatment study in context. Clin Cardiol 33:536-541

11. Mann DL, McMurray JJ, Packer M, Swedberg K, Borer JS, Colucci WS, Djian J, Drexler H, Feldman A, Kober L, Krum H, Liu P, Nieminen M, Tavazzi L, van Veldhuisen DJ, Waldenstrom A, Warren M, Westheim A, Zannad F, Fleming T (2004) Targeted anticytokine therapy in patients with chronic heart failure: results of the Randomized Etanercept Worldwide Evaluation (RENEWAL). Circulation 109:1594-1602

12. Mann DL, Acker MA, Jessup M, Sabbah HN, Starling RC, Kubo SH (2007) Clinical evaluation of the CorCap cardiac support device in patients with dilated cardiomyopathy. Ann Thorac Surg 84:1226-1235

13. Borggrefe MM, Lawo T, Butter C, Schmidinger H, Lunati M, Pieske B, Misier AR, Curnis A, Bocker D, Remppis A, Kautzner J, Stuhlinger M, Leclerq C, Taborsky M, Frigerio M, Parides M, Burkhoff D, Hindricks G (2008) Randomized, double blind study of non-excitatory, cardiac contractility modulation electrical impulses for symptomatic heart failure. Eur Heart J 29:1019-1028

14. Birnie DH, Tang ASL (2006) The problem of non-response to cardiac resynchronization therapy. Curr Opin Cardiol 21:20-26

15. Beshai JF, Grimm RA, Nagueh SF, Baker JH, Beau SL, Greenberg SM, Pires LA, Tchou PJ (2007) For the RethinQ study investigators. Cardiac-resynchronization therapy in heart failure with narrow QRS complexes. N Engl J Med 357:2461-2471

16. Olshansky B, Sabbah N, Hauptman PJ, Colucci WS (2008) The parasympathetic nervous system and heart failure: pathophysiology and implications for therapy. Circulation 118:863-871

17. Schwartz PJ, de Ferrari GM (2011) Sympathetic-parasympathetic interaction in health and disease: abnormalities and relevance in heart failure. Heart Fail Rev. doi:10.1007/s10741-010-9179-1

18. Chapleau MW, Sabharwal R (2011) Methods of assessing vagus nerve activity and reflexes. Heart Fail Rev. doi:10.1007/s10741010-9174-6 
19. Bibevski S, Dunlap M (2011) Evidence for impaired vagal nerve activity in heart failure. Heart Fail Rev. doi:10.1007/s10741010-9190-6

20. Li W, Olshansky B (2011) Inflammatory cytokines and nitric oxide in heart failure and potential modulation by vagus nerve stimulation. Heart Fail Rev. doi:10.1007/s10741-010-9184-4

21. Zhang Y, Mazgalev T (2011) Arrhythmias and vagus nerve stimulation. Heart Fail Rev. doi:10.1007/s10741-010-9178-2

22. Cohen ML, Georgievskaya Z (2011) Histopathology of the stimulated vagus nerve: primum non nocere. Heart Fail Rev. doi:10.1007/s10741-010-9182-6

23. Sabbah HN (2011) Vagus nerve stimulation in experimental heart failure. Heart Fail Rev. doi:10.1007/s10741-010-9209-z
24. Schwartz PJ, de Ferrari GM, Sanzo A, Landolina M, Rordorf R, Raineri C, Campana C, Revera M, Ajmone-Marsan N, Tavazzi L, Odero A (2008) Long term vagal stimulation in patients with advanced heart failure: first experience in man. Eur J Heart Fail 10:884-891

25. Desai M, Watanabe M, Laddu A, Hauptman PJ (2011) Pharmacologic modulation of parasympathetic activity in heart failure. Heart Fail Rev. doi:10.1007/s10741-010-9195-1

26. de Ferrari GM, Schwartz PJ (2011) Vagus nerve stimulation: from pre-clinical to clinical application: challenges and future. Heart Fail Rev. doi:10.1007/s10741-010-9216-0 